\title{
Reverse Auctions and Universal Telecommunications Service: Lessons from Global Experience
}

\author{
Scott Wallsten \\ Technology Policy Institute
}

Follow this and additional works at: https://www.repository.law.indiana.edu/fclj

Part of the Administrative Law Commons, Antitrust and Trade Regulation Commons, and the Communications Law Commons

\section{Recommended Citation}

Wallsten, Scott (2009) "Reverse Auctions and Universal Telecommunications Service: Lessons from Global Experience," Federal Communications Law Journal: Vol. 61 : Iss. 2 , Article 4.

Available at: https://www.repository.law.indiana.edu/fclj/vol61/iss2/4

This Article is brought to you for free and open access by the Law School Journals at Digital Repository @ Maurer Law. It has been accepted for inclusion in Federal Communications Law Journal by an authorized editor of Digital Repository@ Maurer Law. For more information, please contact rvaughan@indiana.edu.

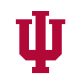

JEROME HALL LAW LIBRARY

INDIANA UNIVERSITY

Maurer School of Law
Blooming ton 


\section{Reverse Auctions and Universal Telecommunications Service: Lessons from Global Experience}

\section{Scott Wallsten*}

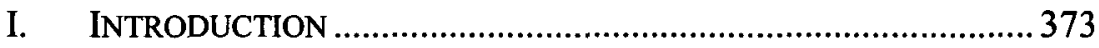

II. UNIVERSAL SERVICE IN THEORY AND IN PRACTICE ................. 377

A. Rationale for Universal Service in Telecommunications. 378

B. Tax and Distribution Schemes are Inefficient .................. 379

C. How Much Should We Spend and Where? ...................... 380

III. GLOBAL EXPERIENCE WITH REVERSE AUCTIONS AND

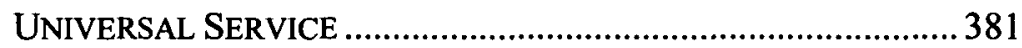

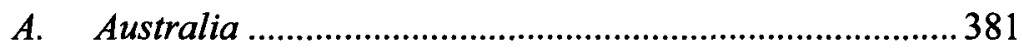

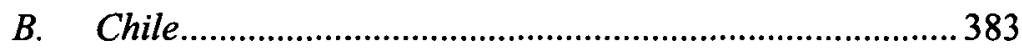

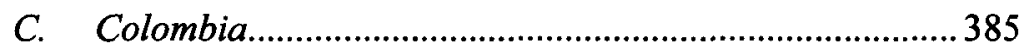

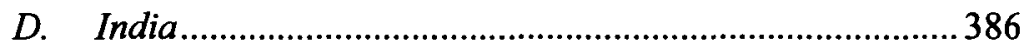

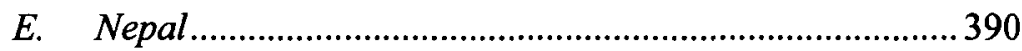

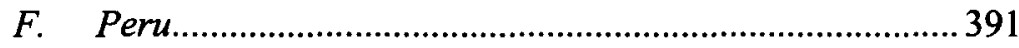

IV. DISCUSSION AND CONCLUSION ......................................... 392

\section{INTRODUCTION}

Nearly every country in the world has universal service or access regulations in an attempt to ensure that everyone in the country can access telecommunications services at affordable prices, although

* April 2008, Vice President for Research and Senior Fellow, Technology Policy Institute. scott@wallsten.net. I thank Stephanie Hausladen for excellent research assistance. All mistakes are my own. The opinions expressed here are my own and do not necessarily reflect those of any of the organizations with which I am affiliated. 
"telecommunications" and "affordable" are not always easy to define. Universal service subsidies are typically used for telecommunications services in rural areas. The United States also subsidizes schools and libraries, and a small share of the subsidies go to low-income people.' Annual spending in the United States on universal service has increased substantially, reaching approximately $\$ 7$ billion in $2007 .^{2}$ Most of this growth is the result of increases in the High Cost Fund (Figure 1). Because these subsidies have been so inefficient, ${ }^{3}$ the mounting expenditures-and thus inefficiencies-are creating increasing pressures to reform the system.

Figure $1^{4}$

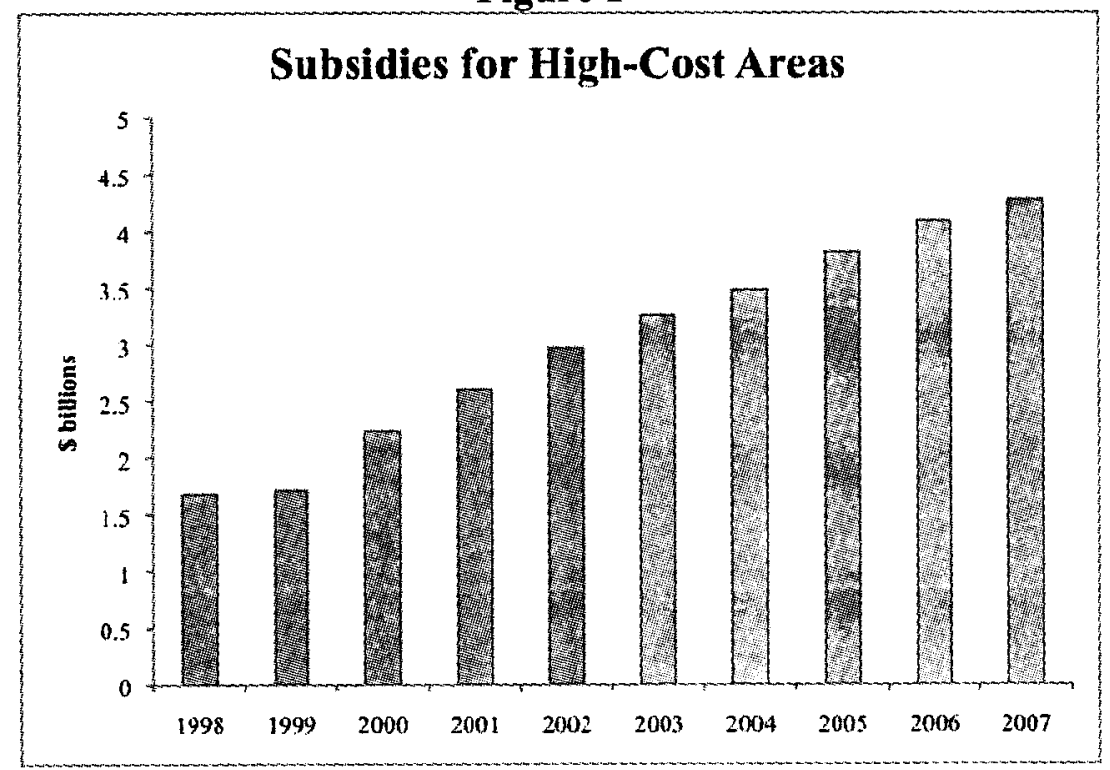

The FCC is considering "reverse auctions" as one possible method of controlling these expenditures. ${ }^{5}$ Paul Milgrom proposed this idea more than

1. See Universal Service Administrative Company, http://www.usac.org/default.aspx (last visited Jan. 30, 2009).

2. See Universal Service Fund Facts - About USF - USAC, http://www.usac.org/ about/universal-service/fund-facts/fund-facts.aspx (last visited Jan. 30, 2009) (data reported by the Universal Service Administrative Company (USAC), a not-for-profit corporation designated as the administrator of the federal Universal Service Fund by the FCC).

3. See, e.g., Gregory L. Rosston \& Bradley S. Wimmer, The 'State' of Universal Service, 12 INFO. ECON. \& POL'Y, 261.

4. This chart was compiled based on data in mandatory, quarterly FCC filings by the USAC which project support requirements. See http://www.usac.org/about/governance/fccfilings/fcc-filings-archive.aspx (last visited Jan. 30, 2009).

5. High-Cost Universal Serv. Support, Notice of Proposed Rulemaking, 23 F.C.C.R. 1467 , paras. $15-16(2008)$. 
a decade ago, ${ }^{6}$ and Dennis Weller developed a more specific proposal. ${ }^{7}$ The general idea is for firms to bid for subsidies, and the firm with the lowest bid - that is, the firm that asks for the smallest subsidy-provides the service. While the United States has never allocated universal service subsidies in this way, it is not untested.

A reverse auction is the standard way in which the government typically procures any good or service. When the government needs to purchase something, it issues a request for proposals (RFP) describing specifically what it wants. ${ }^{8}$ Firms reply to this request, and the government picks the firm that submits the best bid. The best bid may be the lowest, but the government may also take other factors into account when making the decision, especially in the case of complex projects. While it is easier to conduct a reverse auction for simple products, the U.S. government has also used them to supply highly complex goods like weapons systems, ${ }^{9}$ demonstrating that feasible auctions need not be simple.

Since a reverse auction for universal service is simply a RFP to supply telecommunications services, and because no-bid contracts are typically controversial, ${ }^{10}$ perhaps it should be surprising not that the FCC is considering reverse auctions, but instead that reverse auctions have yet to be used for universal service.

In addition, other countries have used reverse auctions to provide universal service with some success. Their experiences demonstrate convincingly that reverse auctions can bring down subsidies substantially. Their experiences also demonstrate that, as in any auction, the rules matter a great deal. India's first attempt at reverse auctions was not successful, failing to reduce the subsidy and concluding with the incumbent as the only winner. ${ }^{11}$ India persisted, and its most recent auction ended with firms

6. See Paul Milgrom, Procuring Universal Service: Putting Auction Theory to Work, Lecture at the Royal Swedish Academy, Canberra (Dec. 9, 1996), (transcript available at http://www.market-design.com/files/milgrom-procuring-universal-service.pdf).

7. See Dennis Weller, Auctions for Universal Service Obligations, 23 Telecomm. POL'Y 645 (1999).

8. See Office of Mmgt. \& Budget, Office of Fed. Procurement Policy, MANAGER's Guide to COMPETITIVE SOURCING (2d ed. 2004), available at http://www.whitehouse.gov/omb/procurement/index_guides.html.

9. See, e.g., David Herszenhorn \& Jeff Bailey, In Tanker Bid, It was Boeing vs. Bold Ideas, N.Y. TIMES, Mar. 10, 2008, at A1, available at http://www.nytimes.com/2008/ 03/10/business/worldbusiness/10tanker.html; see also U.S. Gov'T ACCOUNTABILITY OFFICE, JoInt Strike Fighter: Management of tHE TeChNology Transfer Process (2006), available at www.gao.gov/cgi-bin/getrpt?GAO-06-364.

10. The Competition in Contracting Act of 1984, Pub. L. No. 98-369, 98 Stat. 1175 (codified as amended at 41 U.S.C. $\S 253(2000)$ ), states that the government must do procurement through "full and open competitive procedures."

11. See infra Part III.D. 
bidding for no subsidy and even bidding to pay to provide service rather than to receive subsidies. ${ }^{12}$

This Article surveys global experience with reverse auctions in universal service. In particular, it discusses reverse auctions in Australia, Chile, Colombia, India, Nepal, and Peru and draws lessons from these countries for the United States. Figure 2 gives an overview of reverse auctions in these countries, as well as Guatemala and the Dominican Republic.

Most reverse auctions have been aimed at providing public telephones in developing countries. ${ }^{13}$ While this type of universal service differs from universal service in the United States, these experiences have demonstrated that reverse auctions can reduce subsidies paid for universal service and that, in general, subsidies for universal service have been too high. These experiences also highlight the importance of thinking carefully about how to handle the incumbent given its inherent advantages in information and installed capacity. Overall, global experience demonstrates that if the regulator's goal is to reduce the level of subsidies or to provide information about the "right" level of subsidies, reverse auctions can be successful.

The following Section discusses the theory behind universal service and what it means in practice, while the subsequent Sections discuss these countries' experiences with reverse auctions.

12. Id.

13. See infra Part III.A. Australia is the one industrialized country that has tried the idea while India has used reverse auctions for mobile telephony in addition to public telephones. See DaRYl Williams, Minister for COMM. INFo. TeCh. AND THE ARTS, REVIEW OF THE Operation OF THE UNIVERSAL SERVICE Obligation and CUSTOMER SERVICE Guarantee (2003) (Australia). 


\section{Figure 2: Reverse Auctions for Universal Service in Selected Countries $^{14}$}

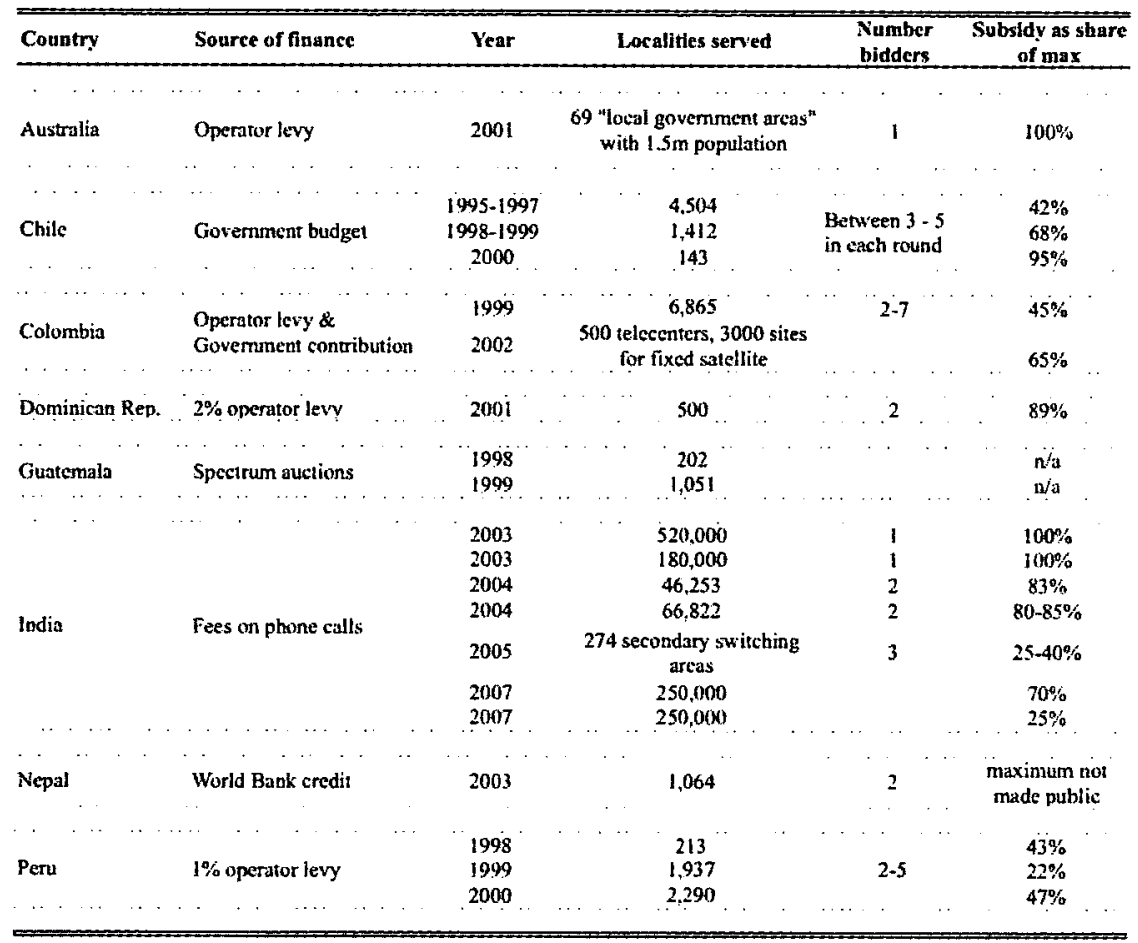

\section{UNIVERSAL SERVICE IN THEORY AND IN PRACTICE}

"Universal service" refers to the idea that an infrastructure utility, such as electricity, transportation, water, or telecommunications, should be

14. The basic table design and much of the data for Chile, Colombia, the Dominican Republic, Guatemala, and Peru are from ANDREW DYMOND \& SONJA OESTMANN, INTELECON Research \& CONSUltancy LtD., RuRal TElecommunications Development in a LIBERALISING ENVIRONMENT: AN UPDATE ON UNIVERSAL ACCESS FUNDS (2002), available at http://www.inteleconresearch.com/pdf/update\%20universal\%20access.pdf. Several other sources contain a table similar to DYMOND \& OESTMANN without attribution. As far as I can tell, that is the original source. Much of the information on the number of bidders comes from Hank Intven \& Curt Howard, Least-Cost Subsidy Auctions for Universal Access Telecom Projects: A Practical Implementation Guide, Presentation at EBRD, IDRC, JICA, Keio University ICT Seminar, slide 10 (Aug. 25, 2004), available at http://www.ictseminar.org/Doc/IntvenAug.25am.ppt. Nepal data are from HANK INTVEN, Edgardo Sepúlveda \& Curt Howard, World Bank, Output-Based Aid In Nepal: EXPANDING TELECOMMUNICATIONS SERVICE TO RURAL AREAS (2004), available at http://www.gpoba.org/publications/approaches.asp. I derive India data from Roger G. Noll \& Scott Wallsten, Universal Telecommunications Service in India, in 2 INDIA POLICY FORUM 2005-06 (2006), and other sources cited in the India section of this report. 
available to everyone. ${ }^{15}$ Universal service policies are typically rationalized in three ways. ${ }^{16}$ First, externalities might make it economically efficient to subsidize prices for those who cannot afford the service at cost. ${ }^{17}$ Positive externalities imply that the total benefits from providing service to an individual exceed the benefits to an individual subscriber. If the private marginal cost of service exceeds the private marginal benefit by less than the amount of the external benefit, then some individuals will not subscribe even though the social benefit of serving them exceeds their cost of service.

Second, some services might be "merit goods"-goods and services that society believes everyone should have, regardless of whether they are willing to pay for those services. ${ }^{18}$ A policy decision that certain goods and services ought to be subsidized may come from a belief that everyone should achieve a certain minimum standard of living or from a concern that individuals are unable to accurately assess the private benefits of consuming these services. If society is more concerned about consumption of the merit goods than the overall welfare of poor people, subsidies for these goods might be preferable to direct monetary transfers because people may choose to spend cash transfers on something other than the service society wants to encourage.

Finally, political factors or regional development goals may induce governments to transfer resources to rural or low-income constituents. ${ }^{19}$ In countries with large rural populations, in which rural areas are generally disproportionately represented, policymakers may face a political incentive to ensure that their rural constituents have access to the same services as do urbanites.

\section{A. Rationale for Universal Service in Telecommunications}

The typical economics argument defending universal telecommunications service is that network externalities result in a suboptimal investment. "Network externalities" occur when the benefits that a new consumer accrues from connecting (the private benefits) are less

15. Noll \& Wallsten, Universal Telecommunications Service in India, supra note 14, at 258-60. This section draws heavily from joint research with Roger Noll with minor changes and additions and is used with permission of the author. Copyright is held jointly by Scott Wallsten, Roger Noll, NCAER and the Brookings Institution. Any opinions expressed in this paper are intended to reflect Wallsten's opinions only.

16. See Helmuth Cremer et al., Econ. Dev. Inst., The Economics of Universal SERVICE: PRACTICE (1998), available at http://www.worldbank.org/wbi/regulationf/pdfs/practice.pdf; see also Helmuth CREMER ET AL., ECON. Dev. INST., THE ECONOMics OF UNIVERSAL SERVICE: THEORY (1998) available at http://www.worldbank.org/wbi/regulat ion-f/pdfs/theory.pdf.

17. See, e.g., CREMER ET Al., THEORY, supra note 16.

18. Id. at 7 .

19. Id. 
than the total benefits to society; when an additional person connects to the network, all other subscribers benefit by being able to communicate with the new subscriber. Therefore, individuals may not face a strong enough incentive to subscribe, thus requiring subsidies to induce socially optimal subscription.

This argument, however, is incomplete and therefore misleading. ${ }^{20}$ First, even if the benefits to the new subscriber are less than the total benefits, the private benefit may still exceed the cost for nearly all subscribers, in which case a general subsidy of service is mostly wasted. Second, because services become more valuable when more people are connected, the firm providing access captures some of the benefits from network externalities. Consequently, although network externalities are external to the individual, they are not necessarily external to firms providing the service, potentially removing the need for subsidies. In other words, network externalities by themselves do not necessarily imply that without subsidies too few people would subscribe to telecommunications services. Third, all subscribers receive an external benefit from subscriptions by others, implying that each person should subsidize the service of the other. Consequently, on average, the subsidy a subscriber receives to take service ought to be roughly equal to the amount of the subsidy that subscriber should be willing to pay to induce others to subscribe.

Even if one disregards the point that the theoretical justification for subsidies is weak and believes that subsidies are nevertheless required, the manner in which we pay for those subsidies is inefficient. In particular, we pay for universal service subsidies by taxing other telecommunications services via cross-subsidies. Economics research provides convincing empirical evidence that the case for extensive cross-subsidization in telecommunications is weak, as discussed below.

\section{B. Tax and Distribution Schemes are Inefficient}

Cross-subsidies in telecommunications are inefficient and costly to society in large part because they tax usage, which has a relatively high price elasticity of demand (e.g., long distance and mobile), in order to subsidize access, which has a very low price elasticity of demand. In other words, our system of funding universal service taxes those services for which people are highly price-sensitive, causing them to change their behavior and use those services less than they otherwise would. Jerry Hausman estimated that each dollar raised in taxes on wireless services

20. For a more complete discussion of this issue, and the points this Author makes regarding it, see Cremer et AL., PraCtice, supra note 16, and CREMER et AL., THeORY, supra note 16. 
costs the economy between $\$ 0.72$ and $\$ 1.14 .^{21}$ Jerry Ellig estimated that taxes on wireless services and interstate long-distance services to support universal service reduced economic welfare in 2002 - when subsidies were lower than they are now - by nearly $\$ 2$ billion annually. ${ }^{22}$

At the same time, those taxes are used to subsidize access, which people are likely to purchase even when prices change. Gregory Rosston and Bradley Wimmer, for example, estimated in a detailed empirical analysis that eliminating the High Cost Fund would reduce telephone penetration by only one-half of one percent. ${ }^{23}$ That estimate is likely to be even smaller today given increased competition and lower costs. Rosston and Wimmer also point out the inequity of the universal service program, finding that eighty percent of poor households pay into the fund through taxes on the telecommunications services they use and get nothing back. ${ }^{24}$

\section{How Much Should We Spend and Where?}

A key problem with universal service is deciding what subsidies are necessary and how to distribute them. In principle, universal service subsidies are necessary when it is not economic for a firm to provide service. In that case, the ideal subsidy would equal the gap between the level of investment a firm would be willing to make and the investment required to provide service.

This cost-based approach has several problems. First, our regulatory history demonstrates that it is not possible to accurately calculate the true costs of providing service. ${ }^{25}$ The task becomes more difficult when the provider has every incentive to make the cost of service appear high. Second, it becomes difficult to change once a firm is providing subsidized service. Potential new entrants would have to compete with a subsidized incumbent. Subsidies could be made available to those firms too, but that risks driving up the cost of the program.

Reverse auctions do not address the way in which universal service funds are collected. Instead, they focus on how those funds are distributed. When designed properly, auctions are a tool that can induce firms to reveal

21. Jerry Hausman, Efficiency Effects on the U.S. Economy from Wireless Taxation, 53 NAT'L TAX J. 733, 735 (2000).

22. Notice of Ex Parte Communication of Mercatus Center, Comprehensive Review of the Universal Service Fund Management, Administration, and Oversight, FCC WC Docket No. 05-195 (rel. Jan. 26, 2006), available at http://www.mercatus.org/uploadedFiles/ Mercatus/Publications/MC_RSP_ExPartePIC2006-02FCCPerfMeasures_060126.pdf.

23. Rosston \& Wimmer, supra note 3 , at 272.

24. See id. at 276-79.

25. See generally, Alfred Kahn, Telecom Deregulation: The Abonimable TELRIC-BS, Address Before the Manhattan Institute (Oct. 1, 2001) (transcript available at http://www.manhattan-institute.org/html/kahn.htm) (weighing the merits of different methods of cost calculation). 
their best guess as to how much it would truly cost to serve an area. Next, different countries' experiences with reverse auctions are discussed.

\section{GLOBAL EXPERIENCE WITH REVERSE AUCTIONS AND UNIVERSAL SERVICE}

Subsidy auctions have been used elsewhere in the world with some success. This Section investigates auctions in Australia, Chile, Colombia, India, Nepal, and Peru. In a fair bidding process with multiple bidders, firms should bid the smallest subsidy necessary for them to provide service. Global experiences reveal that auctions are feasible and that the subsidies required are generally less than incumbents had previously led policymakers to believe.

\section{A. Australia}

In 2000, the Australian government decided to pilot the use of reverse auctions to distribute universal service subsidies in certain areas (see Figure 3 ) ${ }^{26}$ Firms - both the incumbent and its competitors-were to bid for an $\$ 85$ million subsidy to provide standard telephone service in $2003-2004 .^{27}$ This subsidy previously would have been available only to Telstra, the incumbent. ${ }^{28}$ Bidding was to open in July $2001 .^{29}$

As it turned out, none of Telstra's competitors bid to provide service in the pilot regions. ${ }^{30}$ The Australian Department of Communications Information Technology and the Arts (DCITA) ${ }^{31}$ reported that the competitors explained that the subsidy was too low for them to compete with Telstra given Telstra's existing installed capacity and information asymmetry. ${ }^{32}$

DCITA noted that while the results of the pilots were disappointing in that they did not lead to competitive entry, several factors contributed to the outcome, all of which may provide useful lessons. ${ }^{33}$ First, the auctions took place at the beginning of a major downturn in telecommunications markets

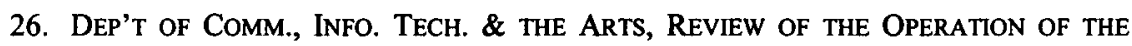
Universal Service Obligation and Customer Service Guarantee $\S 6.2$ (2004) (Australia) [hereinafter DCITA REVIEw], available at http://www.dbcde.gov.au/ data/assets/pdf_file/0005/10103/Review_of_the_Operation_of_the_Universal_Service_ Obligation_and_Customer_Service_Guarantee.pdf.

27. See id. at $\S 6.5$.

28. See id.

29. See id. at $\S 6.2 .3$.

30. See id. at $\S 6.6$.

31. This agency is now called the Department of Broadband, Communications and the Digital Economy.

32. See DCITA REVIEw, supra note 26 , at $\S 6.6$.

33. See id. at $\S 6.9 .1$. 
worldwide.$^{34}$ It is possible that firms were especially risk-averse during this time. Second, the auctions may have revealed that the existing subsidies were not excessive. ${ }^{35}$ Finally, they highlight the need to consider carefully the role of the incumbent when designing these auctions. ${ }^{36}$ As discussed below, India faced similar problems with respect to its incumbent provider.

The unique position of the incumbent raises the important question of identifying the goal of a reverse auction program. In Australia, the goal was to introduce competition. ${ }^{37}$ As Australia's experience shows, however, introducing competition and reducing subsidies are not necessarily consistent, at least in the short run. ${ }^{38}$ As the DCITA pointed out, encouraging competition may have required it to increase its spending on universal service. $^{39}$

34. See id. at $\S 6.9 .1$.

35. See id. at $\S 6.10$.

36. See id. at $\S \S 6.9 .2,6.10$.

37. See id. at $\S 6.2$.

38. See id. at $\S 6.6$.

39. See id. 
Figure $3^{40}$

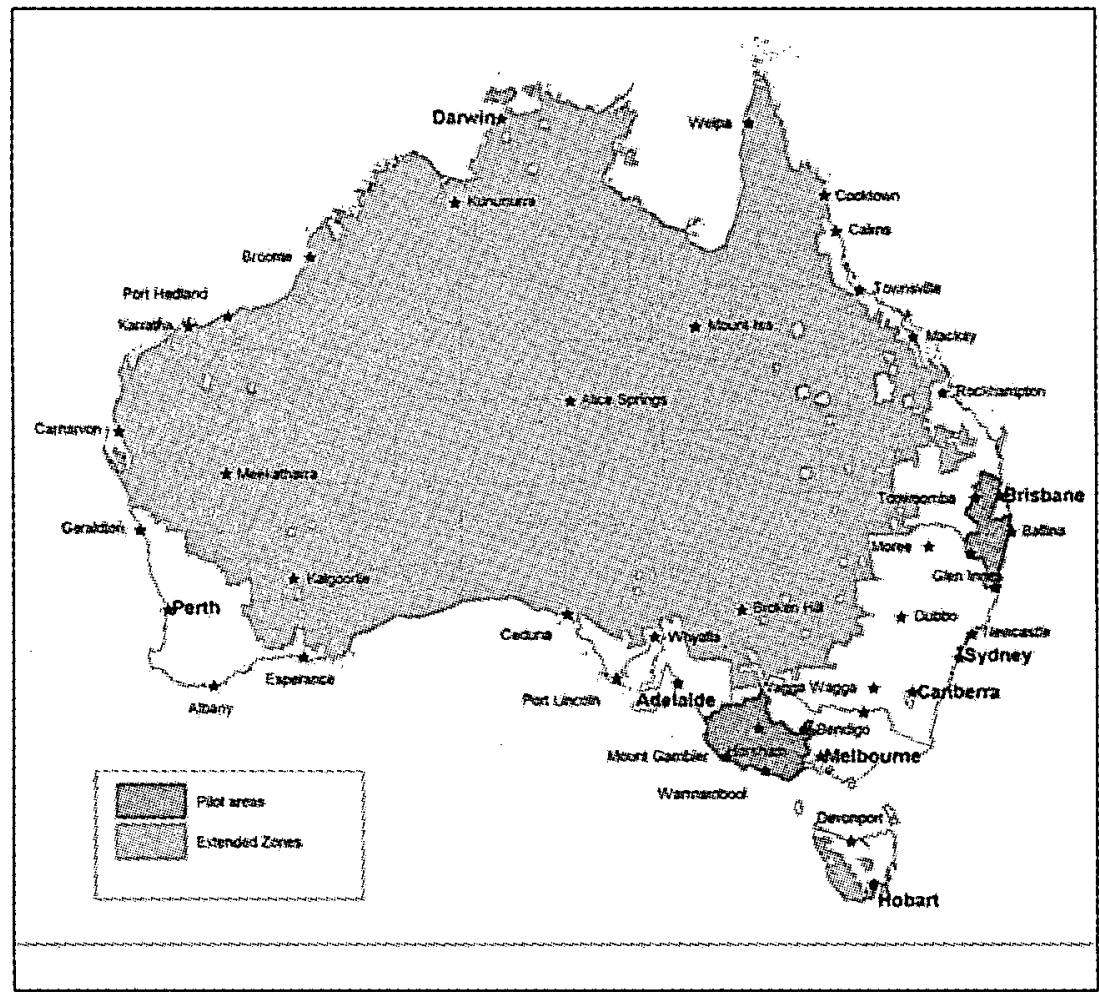

Source: TSI, Connecting Australia, report of the Telecommunications Service Inquin,

September 2000, p. 156

\section{B. Chile}

Chile created its Fondo de Desarrollo de las Telecommunications (Telecommunications Development Fund) in 1994 to provide payphones in rural and low-income urban areas. ${ }^{41}$ Regional and local governments submitted requests for payphones to the regulator, who then determined a maximum allowed subsidy to make the phone commercially viable. ${ }^{42}$ Any firm could bid to provide the service and the winner received a nonexclusive thirty-year license. ${ }^{43}$ The resulting average subsidy was

40. See id. at 60 fig.6.1.

41. See Björn Wellenius, Closing the Gap in Access to Rural Communications: Chile 1995-2002 5 (World Bank Discussion Paper No. 430, 2002), available at http://rru. worldbank.org/Documents/Paperslinks/1222.pdf.

42. See id. at 6.

43. See id. 
US $\$ 3,600$ per payphone, compared to the US $\$ 10,000-$ US $\$ 20,000$ the government had paid previously. ${ }^{44}$

The average subsidy masks two other results that emerged from the bidding process. First, winning bids tended to be either very close to the maximum allowed subsidy or zero. ${ }^{45}$ The dominant local firm bid $100 \%$ of the maximum subsidy in areas with no competitors which were close to its existing network, $90 \%$ of the maximum subsidy in areas with an emerging competitor which were close to its network, and zero in areas with strong competition. $^{46}$ Likewise, the satellite firm Global Village Telecom (GVT) - a Gilat Satellite Networks Ltd. subsidiary, which was a new entrant - bid $100 \%$ of the maximum in areas with no wireline network and did not bid elsewhere. ${ }^{47}$

Intelecon Research and Consultancy Ltd stated, "Chile's fund, which has been in place for four years, did not need to use subsidies at all in 656 of the villages it supplied with telephony, and managed to cover $77 \%$ of the designated villages with only $54 \%$ of the US\$13.3 million of financing it had available."48

The second result was that bidding competition decreased steadily as the auctions proceeded. ${ }^{49}$ Figure 4 shows that the average winning bid increased from $40 \%$ of the maximum subsidy during 1995-1996 to nearly $100 \%$ of the winning bid by $2000 .^{50}$ Björn Wellenius attributed this change to consolidation among telecommunications providers. ${ }^{51}$ Other explanations, however, are also plausible.

It is possible, for example, that the regulator-auctioned areas were expected to be more profitable initially. ${ }^{52}$ In that case, firms would be willing to pay more and accept less to serve those areas and would demand higher payments for serving the less profitable areas that were auctioned later.

Another possibility is that each round of auctions provided the regulator with additional information about the true costs of providing service. The regulator could have used that information to better estimate the maximum subsidy necessary to provide service. If this occurred, one would expect bids to come close to the estimated maximum.

44. See id. at 17.

45. See id.

46. See id.

47. See id.

48. Intelecon, Rural Telphony Market - Still Small But Growing Fast, http://www.inteleconresearch.com/pages/reports-06.html (last visited Jan. 30, 2009).

49. See Wellenius, supra note 41 , at 18.

50. See infra, fig.4; see also Wellenius, supra note 41 , at 18 tbl.8.

51. Wellenius, supra note 41 , at 18.

52. See id. at 10-11. 
Figure $4^{53}$

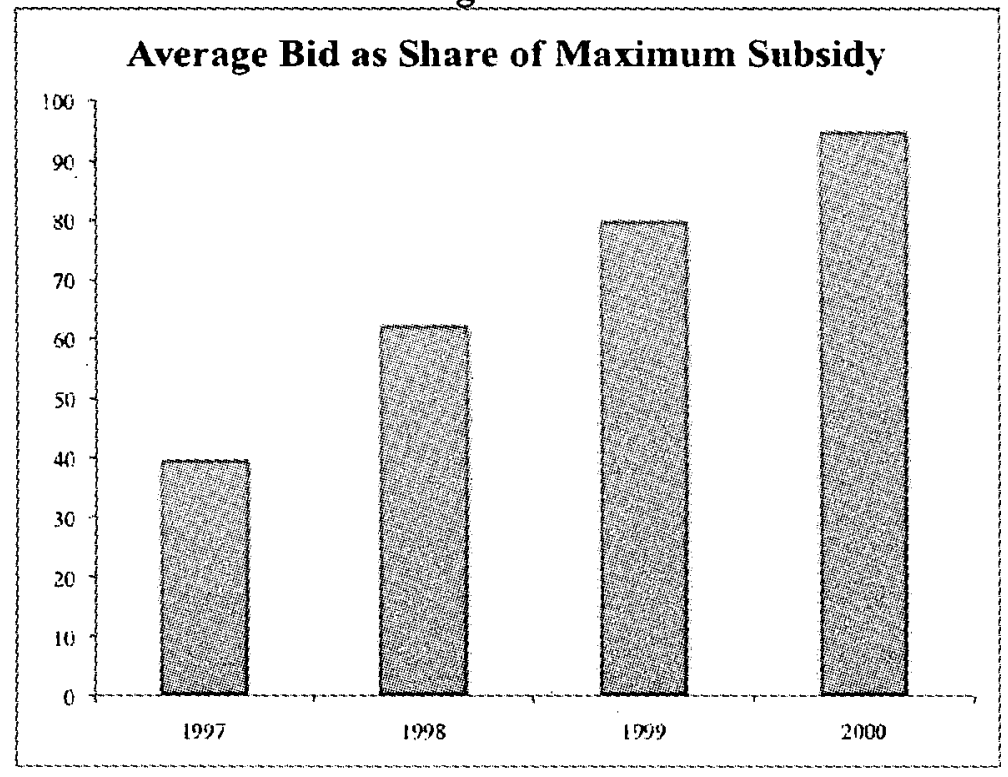

\section{Colombia}

Colombia first used subsidy auctions in 1999 through its Compartel Program after a 1998 government report showed that few rural areas had telecommunications access. ${ }^{54}$ Intelecon Research \& Consultancy described the broad goals of the program:

The Compartel Program aims to afford coverage to every municipality in Colombia through the provision of community use telephones and Internet community access centres.

Compartel auctions social telephony projects across various regions of the country. The Program guarantees the operation and maintenance of the telephones for 10 years. Winning bidders are selected based on meeting technical requirements with the smallest subsidy requested. ${ }^{55}$

GVT won the first auction in 1999 and provided 6,745 telephones and 670 Internet access points. ${ }^{56}$ GVT received about US $\$ 32$ million out of the US\$71 million that had been available. ${ }^{57}$

53. See id. at 18 tbl. 8 .

54. See Siddhartha Raja, Funding Universal Service: A Case for Subsidy Auctions 16 (2003) (unpublished paper, on file with Stanford Univ. Dep't of Mgmt. \& Eng'g), available at http://www.geocities.com/sidheartraja/documents/Paper-FINAL.pdf.

55. INTELECON RESEARCH \& CONSULTANCY LTD., UNIVERSAL ACCESS FundS 14 (2006), available at http://www.inteleconresearch.com/pages/documents/UAFunds2007update.pdf.

56. See id.

57. See DyMOND \& OESTMANN, supra note 14 , at 3. 
The second auction was held in December $2000 .{ }^{58}$ Only one firm bid for subsidies to install " 21,500 residential lines and 61 community Internet centers by April 2002." The Communications Ministry, however, declared the results of this auction invalid due to "various anomalies and omissions in the information supplied by [the sole bidding company]."

The third auction occurred in November 2002 for the installation and operation of 500 telecenters for telephone and Internet service and also for building a 3,000-site fixed satellite network for rural areas over six years. ${ }^{61}$ GVT won this contract after bidding for US\$65 million in subsidies out of the US $\$ 100$ million that had been available. ${ }^{62}$ Intelecon reported that this network was operational by the fourth quarter of $2003 .^{63}$

\section{India}

India's Universal Service Fund (USF) is intended to reimburse the net cost (costs minus revenues) of providing rural telecom service. ${ }^{64}$ Because costs may vary across different types of service and different service segments, separate auctions determine the actual reimbursement to be awarded for each. When awarding licenses for cellular telephone service, the Department of Telecommunications (DoT) divided the country into twenty telecom "circles" (which loosely follow state boundaries). These circles were used as the basis for geographic reference in the rural subsidy auctions.

Telecommunications firms submitted bids to provide service. The firm that bid for the lowest subsidy, as long as the bid was no higher than a set benchmark, was eligible to be reimbursed for that amount from the fund. Benchmarks were set using information primarily from the incumbent, Bharat Sanchar Nigam Ltd. (BSNL). Any firm with a license to provide basic or cellular service in the relevant service area was eligible to bid. The winner received a subsidy for seven years, subject to review after three years.

58. See Raja, supra note 54 , at 16.

59. Id.

60. Id. at 16-17.

61. See INTELECON, UNIVERSAL ACCESS FUNDS, supra note 55, at 17.

62. See Raja, supra note 54, at 17; see also Gilat Satellite Networks Ltd., Annual Report (Form 20-F) (Mar. 6, 2003).

63. See INTELECON, UNIVERSAL ACCESS FUNDS, supra note 55, at 14.

64. Noll \& Wallsten, Universal Telecommunications Service in India, supra note 14, at 255-69. This section draws heavily from joint research with Roger Noll with some changes and additions and is used with permission of the author. Copyright is jointly held by Scott Wallsten, Roger Noll, NCAER and the Brookings Institution. Any opinions expressed in this Article are intended to reflect Wallsten's opinions only. 
India held several auctions, each for different types of telecommunications services. ${ }^{65}$ The first, in March 2003, was to install village public telephones (VPTs) in 520,000 villages. The second, in September 2003, was to replace about 180,000 Multi Access Radio Relaybased VPTs. The third, held in September 2004, was to provide additional rural community phones in about 46,000 villages. The fourth, in November 2004 , was to install VPTs in the 66,000 villages that had no public telephone facilities. The fifth, in March 2005, was to provide direct rural exchange lines in 227 regions. The most recent auction took place in April 2007 to provide mobile services.

The auctions yielded dramatically different results. The first two subsidy auctions, relating to Primary VPTs and replacing Multi Access Radio Relay-based VPTs, were disappointing. In nineteen of the twenty circles only one firm bid for the subsidies, the incumbent BSNL. Not surprisingly, given the thin market, BSNL bid exactly the benchmark amount, which was the maximum subsidy DoT was prepared to provide. By the final auction, however, some firms even bid negative amounts, demonstrating that they were willing to pay to provide service. ${ }^{66}$

At least three problems led to the failure of the first two auctions to create genuine competition for rural public service. First, the calculations for the benchmark subsidy were not plausibly based on accurate information or on the appropriate standard, which is the incremental cost of public telephone service. The cost data used for calculating these benchmarks were provided primarily by BSNL. While there were rigorous independent attempts to verify the information, BSNL's accounts are aggregated in a way that makes it impossible to separate costs for different operations, which in turn makes incremental cost calculations extremely difficult. $^{67}$

Second, callers pay "access deficit charges" (ADCs), which are surcharges on telephone calls that, in theory, help pay for existing service in unprofitable areas. BSNL received nearly all of the ADC crosssubsidies. The incumbent has potential gains from manipulating how cost information is aggregated across service categories and across high-cost and low-cost areas because these data determine not only the benchmark subsidy for public telephones, but also the magnitude of the net deficit for all local access service. If some ambiguous cost elements are allocated to

65. Data derived from $i d$. at 268.

66. See, e.g., At Your Service; Telecoms in the Developing World, Economist, Mar. 31, 2007 at 75.

67. See, e.g., Letter from T.V. Ramachandran, Dir. Gen., Cellular Operators Ass'n of India, to Shri Pradip Baijal, Chairman, Telecom Regulatory Auth. of India (June 4, 2003), available at http://www.coai.in/docs/adc-letter-TRAI.pdf. 
subsidized areas, the effect will be to increase both the public telephone subsidy and the ADC subsidy.

Third, bidding was open only to basic service operators already providing rural service in the area. BSNL, even though it historically had not served many villages, owned some facilities in these areas; however, few other firms had entered these markets, in part because they were opened only recently and in part because disputes about the terms and conditions of interconnection with BSNL remained unresolved.

The fact that the first two auctions covered VPTs in areas in which the incumbent operator had already built infrastructure gave the incumbent a distinct advantage and limited the ability of private operators to compete. Firms not yet operating could bid for the public telephone subsidy only if no other bids were received or if the bids by others exceeded the benchmark. By precluding firms that were not already present, the subsidy scheme did not encourage either entry or innovation in rural services.

The auction procedure that the DoT set up advantaged the incumbent while providing no incentive to improve efficiency. In particular, if only a single firm can qualify for the subsidy and if that firm is then reimbursed the difference between its own estimates of its revenues and costs, the subsidized firm has no incentive to reduce these costs unless it can do so in ways that can be hidden from the DoT. Moreover, with only one subsidized firm in the entire nation, even benchmark competition (whereby differences between monopolies in different areas are used to evaluate performance and adjust the subsidy) is impossible, while the subsidies themselves make it impossible for nonsubsidized firms to enter the market.

The subsidy scheme for encouraging investment in VPTs was only the first part of the reverse auction plan. The following three auctions were more successful, attracting additional firms and yielding better outcomes. While the incumbent won one of those three auctions and parts of the other two, private providers won parts of two auctions, and the subsidies in all three auctions were well below the benchmark amounts.

In September 2004, the government held an auction to provide a second VPT in 300 areas (called secondary switching areas, or SSAs) that already had one. The incumbent BSNL and Reliance Infocomm were the largest winners, and two carriers bid against each other in 115 out of the 300 SSAs. The total subsidy awarded was seventeen percent below the benchmark amount.

A fourth auction in November 2004 was for the obligation to provide VPTs in the remaining 67,000 villages without one. The incumbent BSNL won in all twelve service areas. It faced bidding competition in three service areas, and that competition reduced the total subsidy by fifteen to twenty percent. 
A fifth auction for subsidies to install rural household phones was concluded in 2005 as a first step toward distributing funds for connecting individual households. This step is potentially far more important than the first. Many more telephone lines were at stake in devising a plan for implementing extensive residential access than for providing more public telephones. While even in the best of circumstances firms might not have found subsidies for a relatively small number of public telephones an attractive basis for entering rural areas, subsidies for a much larger number of residential lines clearly are more attractive.

Indeed, the 2005 auction generated more interest among private operators, and the bidding reduced subsidies by sixty to seventy-five percent of the benchmark. BSNL won subsidies for 1,267 Short Distance Charging Areas (SDCAs, the basic service unit identified for subsidies) while two private operators won subsidies for 418 SDCAs.

In 2007 , the government conducted two auctions for mobile service in eighty-one "clusters" that include 250,000 villages. ${ }^{68}$ The first auction was for the right to build infrastructure that could be used by other firms to provide service. $^{69} \mathrm{BSNL}$ won eighty percent of the $\$ 570$ million to build this wholesale infrastructure. ${ }^{70}$ Although BSNL dominated the winning bids, bidding competition reduced the subsidy to thirty percent below the benchmark. $^{71}$

The second mobile auction in 2007 was to provide service over this "passive" network. Bidding was so intense that in many cases the winning bid was either zero or negative, meaning that the operator was willing to pay the government for the right to provide service. ${ }^{72}$ The Economist noted:

This week the government was to have announced the winners of an auction of the rights to create and run networks in remote rural areas. Around the world, such networks are often subsidised by a "universal service fund" (USF) paid for by taxes on existing telecoms services. Auctions are held, and the network operators that demand the smallest subsidies win. They must then provide a certain number of public payphones, as well as signing up subscribers.

But something rather odd happened in India: in 38 of the 81 regions on offer, many mobile operators bid zero. In other words, they asked for no subsidies at all. In 15 regions, India's biggest operator, Bharti

68. BSNL Bags $80 \%$ of Rs 2,500-Crore Rural Mobile Telephony Project, HINDU, Mar. 28, 2007 [hereinafter BSNL Bags Project], available at http://www.hinduonnet.com/ thehindu/holnus/006200703280310.htm; Thomas K. Thomas, RCom, BSNL Bag Bulk of Rural Cellular Project, HINDU Bus. LINE, Apr. 13, 2007, available at http://www.blonnet.com/2007/04/13/stories/2007041305150100.htm.

69. See BSNL Bags Project, supra note 68.

70. Id.

71. Id.

72. At Your Service, supra note 66, at 75. 
Airtel, even offered to pay. As a result, barely one-quarter of the 40 billion rupees $(\$ 920 \mathrm{~m})$ available in subsidies is likely to be allocated. If operators reckon there is money to be made running mobile networks even in some of the poorest parts of the world, have USFs had their day? ${ }^{73}$

Unfortunately, it is not quite as easy to interpret these results as The Economist would suggest. These auction results demonstrate strongly that competition for subsidies can bring down the subsidy. Because these appeared to be bids to operate on a network being built by someone else, it is unclear why subsidies would be offered in the first place. The government of India apparently decided to separate ownership and operation of the network from service provision. The wisdom of such structural separation is heavily debated and centers on whether consumers are ultimately better off when firms compete by investing in facilities or by offering service over the same facilities. Mandatory sharing of network facilities is likely to lead to more intensive use of those facilities, but can also reduce the incentive to invest in the network itself.

In this case, we do not know what the bidding might have revealed if firms had bid simply to provide service at the lowest cost.

\section{E. Nepal}

In 2000, the Nepalese government decided to use a reverse auction process to provide telecommunications service to the 534 village development committees (VDCs-the second-smallest administrative units in Nepal) that had no such access. ${ }^{74}$ Firms were to bid for a one-time subsidy and a ten-year renewable license with a five-year exclusivity guarantee. ${ }^{75}$ In exchange, they were to provide two public access lines in each VDC. ${ }^{76}$ Unlike most reverse auctions, in Nepal, the maximum available subsidy was not made public. ${ }^{77}$

Two firms bid in September 2000, but a "security situation" caused the winning firm to back out of its agreement. ${ }^{78}$ The regulator, the Nepal Telecommunications Authority, attempted the auction again in 2003 with more success. ${ }^{79}$

Two firms bid in the 2003 auction, and the winning bidder asked for approximately US $\$ 11.9$ million to do the project. ${ }^{80}$ The winner appeared to

73. Id.

74. INTVEN, SEPÚlVEDA \& HOWARD, supra note 14.

75. Id.

76. Id.

77. Id.

78. Id.

79. Id.

80. Id. 
be on track to meet its first three rollout agreements by the end of $2004 .^{81}$ The company notes that after rolling out service to more than 500 villages in 2004 , it now serves "over 1,800 sites" and plans to expand service into western Nepal. ${ }^{82}$

\section{F. Peru}

Peru conducted reverse auctions from 1999 to 2001 for service in areas the regulator determined unprofitable. These included rural towns as defined by the National Institute of Statistics and Data Processing, district capitals with 3,000 inhabitants, areas without basic telecommunications services, sparsely populated areas, isolated villages, and poor areas. ${ }^{83}$ The Organismo Supervisor de Inversion Privada de Telecomunicaciones (OSIPTEL) plan was to first auction subsidies for payphones, followed by Internet access, and finally subscriber-fixed telephony. ${ }^{84}$

For the first auction, firms bid for the twenty-year non-exclusive licenses to provide service in six regions of the country. ${ }^{85}$ Winning firms were required to install at least one public payphone in each rural locality and public Internet access in each district capital. ${ }^{86}$ The regulator had allocated US $\$ 150$ million for the project, paid for by a one percent tax on all telecommunications revenue. ${ }^{87}$ The bidding process reduced the total allocated to US\$50 million. Winning firms used a range of wireless technologies, including Very Small Aperture Terminals and wireless local loops. ${ }^{88}$

The number of telephones and payphones per capita increased substantially following the auction process. While the auction seems to have effectively reduced the subsidy granted for providing these rural services, several factors make it difficult to truly evaluate the program's effectiveness.

81. Id.

82. STM, The DVB-RCS VSAT Leader - STM in Nepal, http://www.stmi.com/index. php?option=com_content\&task=view\&id=125\&Itemid=277 (last visited Jan. 30, 2009).

83. Jorge $\mathbf{M}^{-}$. Bossio, Universal Access Funds in Latin America, Presentation for UNCTAD Expert Meeting, at slide 28 (Nov. 14-16, 2006) (slides available at www.unctad.org/sections/wcmu/docs/clem30p026_en.pdf).

84. Id. at slide 26.

85. Geoffrey Cannock, Telecom Subsidies: Output-Based Contracts for Rural Service in Peru, VIEWPOINT (World Bank), June 2001, at 2.

86. Id.

87. Harsha de Silva, What Regulators Can Do To Facilitate Universal Service: Universal Service Funds and Least-Cost Subsidy Auctions, Presentation given in Singapore, at slides 6, 10 (Feb. 27, 2007) (slides available at http://www.limeasia.net/wp-content/ uploads/2006/02/Malik\%20de\%20Silva\%20Sept $\% 202005 \% 20$ final.pdf).

88. See Raja, supra note 54. 
First, countries around the world began liberalizing their telecommunications sectors in the 1990s, leading to rapid increases in investment. ${ }^{89}$ An increase in Peru, therefore, cannot simply be attributed to one policy intervention absent a well-designed test of its effectiveness. Second, some winning firms did not meet their rollout obligations. ${ }^{90}$ Assuming corruption was not a factor, a "winner's curse" might have left firms unable to provide service profitably. That is, the winning firms may have underestimated the costs of meeting the obligations and bid too little. ${ }^{91}$ Finally, winning firms were given spectrum rights to provide service. The true subsidy, therefore, includes not just the US\$50 million granted to the winning firms, but also the opportunity cost of these spectrum rights.

\section{DISCUSSION AND CONCLUSION}

In principle, reverse auctions are simple. The government defines say, a region, and asks for bids to provide service. Firms submit bids of how much the government would have to pay them to provide service in that region. The firm that asks for the smallest subsidy, all else being equal, wins the reverse auction and thus agrees to provide service in exchange for the subsidy it bid.

While the United States has not taken this approach for telecommunications, it may be the most common method the government uses when purchasing goods and services from the private sector. With most large purchases, a government agency issues an RFP describing in detail the product it wants to acquire. These products can be as simple as reams of papers or as sophisticated as tankers used to refill fighter jets in flight or supercomputers used for weapons testing and weather forecasting. Firms wishing to win this business submit bids and, all else being equal, the firm submitting the lowest bid wins the right to provide the service.

The details of a reverse auction, however, are different from most procurement requests. When designing these auctions, policymakers have several difficult questions to answer. Should multiple firms be able to win in any given area, or should only a single firm win each auction? The advantage of allowing multiple firms to win is that it can create competition in the market for services. The disadvantage is that it could drive up universal expenditures substantially, negating part of the purpose of the auctions.

89. Scott Wallsten, An Econometric Analysis of Telecom Competition, Privatization, and Regulation in Africa and Latin America, 49 J. OF INDUS. ECON. 1, 5 (2001).

90. Payal Malik \& Harsha De Silva, Diversifying Network Participation: STUDY OF INDIA's UNIVERSAL SERVICE INSTRUMENTS (2005) at 23.

91. See de Silva, supra note 87 , at slide 17 . 
How should reverse auctions continue over time in a given geographic area? The question of how to proceed after the auctions may be especially important if only one firm wins. In that case, firms compete for the market rather than in the market, meaning that there must be some future competition for the market.

Reverse auctions for universal service have been employed in several other countries around the world. One lesson is clear: details of the auction matter. A poorly designed auction may not generate any improvement over the status quo.

The second lesson is that reverse auctions can be implemented successfully. When done properly, they may reduce expenditures on universal service. That is, the auctions create a market where none existed and use that market to reveal the expected costs of providing telecommunications services. The information may not be complete, depending on the degree of competition, but it improves on the situation prior to the auction.

Many of the cases discussed in this paper are not directly comparable to providing universal service in the United States. In particular, the schemes intended to supply a payphone to a town or village would not be repeated in the United States, and it is presumably easier to define precisely what a bid is for under those conditions. In an auction, the good or service being sold must be well-defined or bidders will have difficulty assigning values to it.

Dale Lehman wrote that these experiences have little applicability in the United States: "It is also worth noting that the 'successful' Latin American reverse auctions rely, in part, on asymmetric interconnection fees to support rural providers. For example, the largest Chilean rural operator gets $60 \%$ of its total revenues from such charges; Colombia has recently introduced asymmetric fees, and Peru plans to." 92

Lehman is correct in noting that these asymmetric fees are problematic. The claim that the presence of these fees means that the auctions may not have been a success, however, is probably incorrect. In a fair auction, the bidders take into account all future streams of income (and expenses) when making their bids. Bids, presumably, thus take into account expectations of these asymmetric fees. More importantly, as a result of the auctions, governments spent less subsidizing universal service than they would have otherwise.

92. Dale E. Lehman, The Use of Reverse Auctions for Provision of Universal SERVICE app. A, 20, submitted with Nat'l Telecomm. Coop. Ass'n Initial Comments, Federal-State Joint Board on Universal Service Seeks Comment on the Merits of Using Auctions to Determine High-Cost Universal Service Support, FCC WC Docket No. 05-337 (rel. Oct. 10, 2006). 
As discussed above, while reverse auctions may be a new way to distribute funds for universal telecommunications service, it is the standard way the U.S. government procures most goods and services. In addition, several countries around the world have used reverse auctions to distribute universal service funds. Most of these reverse auctions have been successful in reducing expenditures on universal service. In two cases the auctions did not reduce expenditures (Australia, and the first and second auctions in India), but even there, expenditures were not more than they would have been without an auction.

However, policymakers must carefully consider two issues. First, they must take into account the effects of the incumbent's information advantages and existing infrastructure, which can advantage it relative to potential competitors. Second, policymakers must be clear about their objective. The existing evidence shows that reverse auctions can effectively reduce expenditures by promoting competition for the market rather than competition in the market. Reducing expenditures on universal service may not be consistent, at least in the short run, with increasing competition in a given geographic market.

In sum, reverse auctions have proven themselves both feasible and effective mechanisms for reducing expenditures on universal service and for revealing information about the true costs of supplying service in rural areas. Assuming these policy goals, policymakers in the United States should, at a minimum, devise pilot projects to begin implementing this idea. 